\title{
Mantle Sections Beneath Yakutian Kimberlites, Thermobarometic Study
}

\author{
Igor V. Ashchepkov ${ }^{1}$, Nikolai P. Pokhilenko ${ }^{1}$, Nikolai V. Vladykin ${ }^{2}$, Alla M. Logvinova ${ }^{1}$, \\ Valentin P. Afanasiev ${ }^{1}$, Lyudmila N. Pokhilenko ${ }^{1}$, Sergei S. Kuligin ${ }^{1}$, Anatoly Y. Rotman ${ }^{3}$, \\ Olga S. Khemelnikova ${ }^{1}$ and ElenaV.Vishnyakova ${ }^{4}$.
}

\author{
${ }^{1}$ Institute of Geology and Mineralogy SD RAS, Novosibirsk, Russia \\ ${ }^{2}$ Institute of Geochemistry SD RAS, Irkutsk \\ ${ }^{3}$ Central Scentific Research Geological Prospecting Institute, ALROSA Co Ltd, Mirny, Russia, \\ ${ }^{4}$ Novokuznetsk Metallurgical Factory, Novokuznetsk, Russia
}

Thermobarometric study of mantle lithosphere Siberian kimberlites (Sobolev, 1977) is restricted by the high alteration stage of the most of mantel xenoliths except for Udachnaya, Mir, Onazhennaya and some other pipes. Mineral thermobarometry allow receiving the general regularities of the mantle sections (Ashchepkov et al., 2003; 2008).

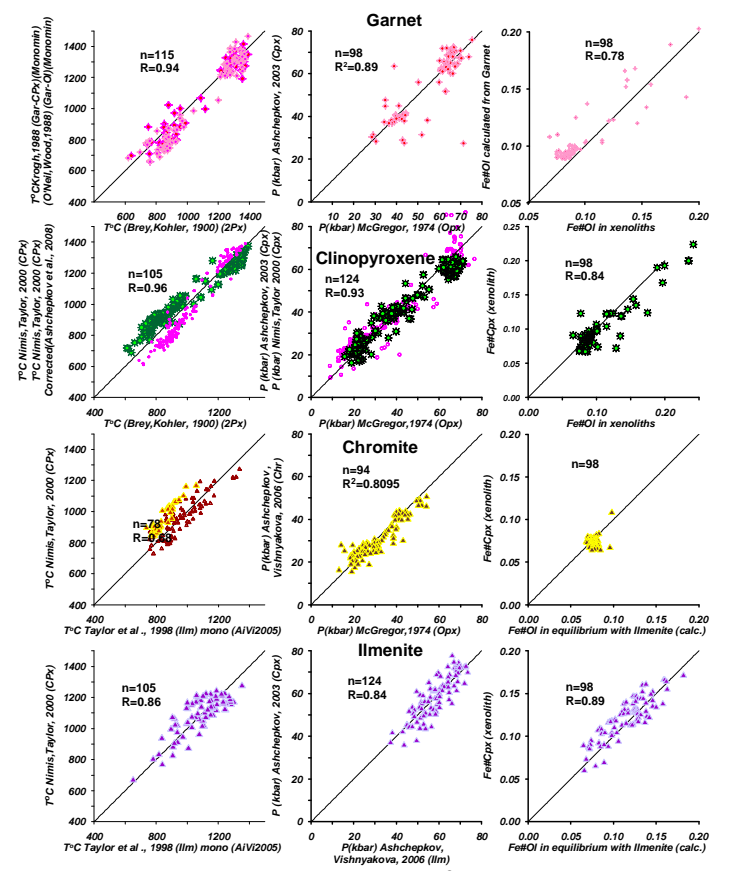

Fig1. Correlations between $\mathrm{T}^{\circ} \mathrm{C}, \mathrm{P}(\mathrm{kbar})$ received by monomineral and common methods of mantle thermobatometry and Fe\#Ol calculated vs xenoliths.

Opx thermobarometry for mantle beneath Udachnaya give not only low-temperature (LT) branch (Boyd et al., 1997) close to conductive obtained with common thermometers (Krogh, 1988; O’Neill, Wood, 1979; etc) but also two more HT- PT paths of mantle melts. Three branches are be reproduced by the substitution in the thermometers Ol-Sp and Gar-Ol ro Cpx different values of Fe\# $(0.07,0.085$ and 0.11). Modified thermobarometric equations for Garnet, Chromite and Ilmenites (Ashchepkov et al., 2008) take in to account the Fe\# for coexisting olivines and other minerals calculating using regressions between xenolith's minerals with TP values (plotted in fig.1) and correlation lines between monomineral and common methods of mantle thermobarometry. Thermometer of (Krogh, 1988) with Al- barometer (McGregor, 1974) reproduce LT branch. Essentially modified (O'Neill, Wood, 1979) thermometer with the new corrections to $\mathrm{Ca} / \mathrm{Mg}$ ratios reproduces the more HT path.

Reguliaritied of mantle sections and layering in Daldyn field are recognized on the TP and P-X diagrams.

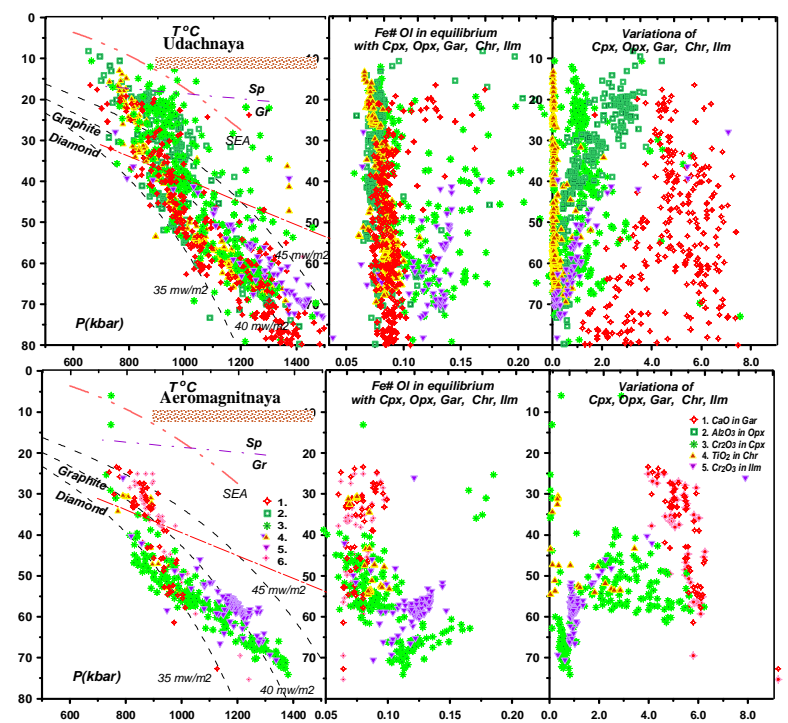

Fig.2. TP estimates for mantle sections beneath Daldyn kimberlite pipes. $1 . \quad$ Gar-monomineral thermobarometry: $\mathrm{T}^{\circ} \mathrm{C}$ (Krogh, 1988, monomineral) - P kbar (Ashchepkov, 2006); 2. the same $\mathrm{T}^{\circ} \mathrm{C}$ (O'Neil, Wood, 1979 monomineral); 3. Opx: $\mathrm{T}^{\circ} \mathrm{C}$ (Brey \& Kohler, 1990) - P(kbar) (McGregor, 1974); 4.Cpx $\mathrm{T}^{\circ} \mathrm{C}$ (Nimis \& Taylor, 2000) - $\mathrm{P}(\mathrm{kbar})$ (Ashchepkov, 2003) for peridotites; 5. Chr: $\mathrm{T}^{\circ} \mathrm{C}$ (Taylor et al., 1998) - P(kbar) (Ashchepkov \& Vishnyakova, 2006) 6. Ilm: $\mathrm{T}^{\circ} \mathrm{C}$ (Taylor et al., 1998) - $\mathrm{P}(\mathrm{kbar})$ (Ashchepkov\& Vishnyakova, 2006) 
Thermal conditions of the lower part of mantle sections were heated by the protokimberlite melts created the megacrystalline associations. TP values of subcalsic garnets are correlating with those of picroilmenites. Large pipes like Udachnaya reveal complex layering consisting from 12-13 units correlating with the peaks of Re/Os ages (Spetsius et al., 2007) and plume events. Large amounts of pyroxenites and 'hot' eclogites (Pokhilenko et al., 2000) are found in $\sim 55-65, \sim 40$ and $50 \mathrm{kbar}$. For smaller pipes the layering in mantle is less visible but fertilizations with Cr-low pyroxenes also associates with the protokimberlite influence.

Mantle sections of Alakite field are subjected to pervasive metasomatism in several stages, the latest create the Fe-enriched $\mathrm{Cr}$-diopsides and some low-Ca garnets probably near the melt feeders. For mantle columns beneath the Aykhal pipe ilmenite TP trends were formed at least in the 3 stages, the major magmatic source at $60-70$ kbar was accompanied by the HT metasomatites. Rising protokimberlites to 50 kbar was accompanied by $\mathrm{Cr}$ - enrichment according to AFC (DePaolo, 1981). Mantle layering is emphasized by the stepped Fe\#-rise of garnets found in 10 intervals. In mantle lithosphere beneath Komsomolskaya the layering is visible in 6 sharp intervals. Ilmenites forming magmatic systems were found in two intervals 70-58 and 54-43 kbar, rise of $\mathrm{CaO}$ for garnets in these intervals or $\mathrm{Ca}$-decrease is correlating with $\mathrm{Cr}$ - rise of clinopyroxenes.

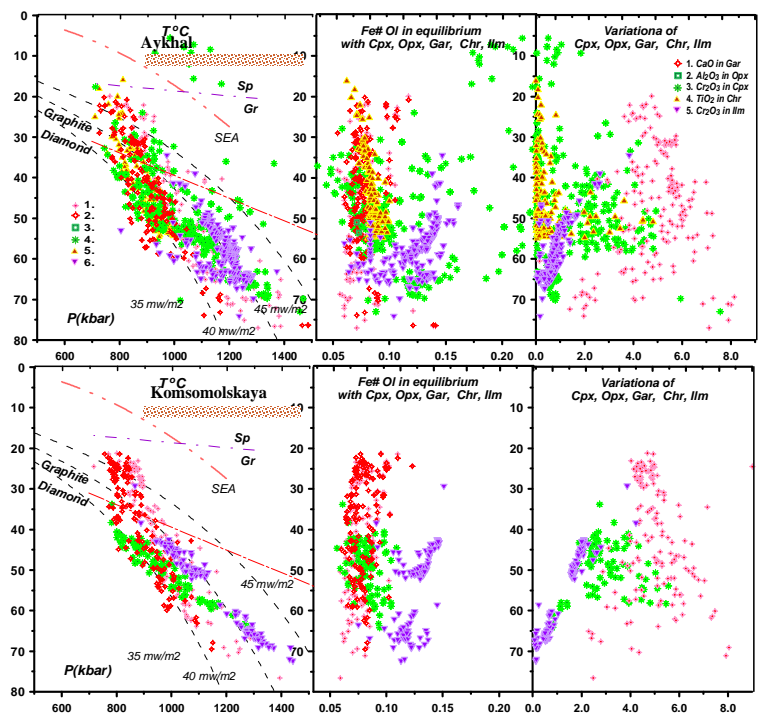

Fig.3. TP estimates for mantle beneath Alakite pipes.

In Malo-Botuobinsky field mantle section beneath Mir pipe is subjectet to heating from base to $45 \mathrm{kbar}$ due to protokimberlites created $\mathrm{Cr}$ - less picroilmenites. $\mathrm{Cr}$ ilmenites appear in metasomatites upper. Low- $\mathrm{Ca}$ garnets in this interval corresponds to several (7) layers probably reflecting primary subduction horizons. Depletion formed low- Ca (Ti-bearing) - garnets partly refer to the last plume event. Thick dunite-harzburgite lens is detected by chromites $\sim 50-60$ kbar. Layered lherzolite sequence with abundant pryroxenites and metasomatites constitutes 4 units upper (45- $30 \mathrm{kbar}$ ). Heating detected by garnets TP values refers to those found for ilmenites. Layering in mantle beneath International'naya is overprinted by metasomatism from the base to $50 \mathrm{kbar}$ where HT pyroxenites and picroilmenites occur.
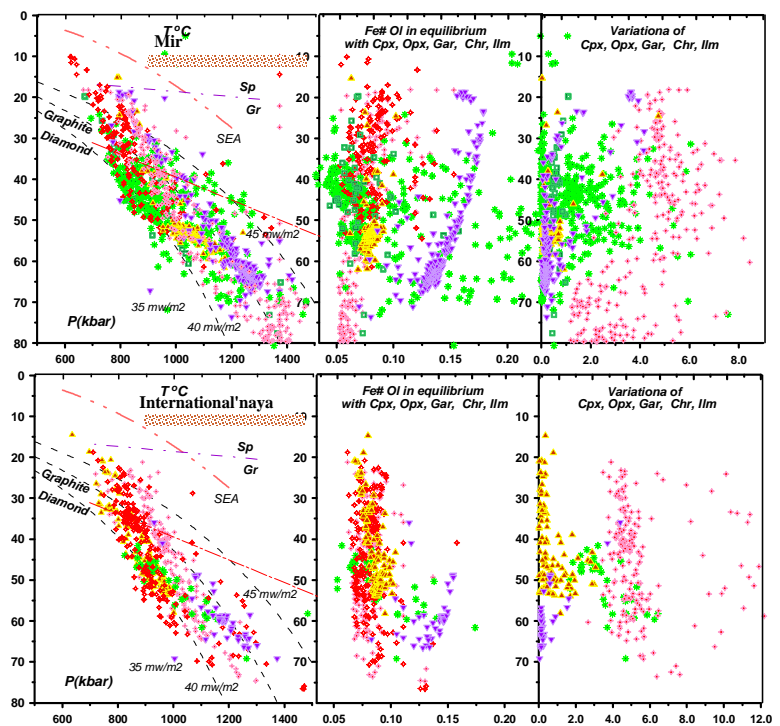

Fig.4. TP estimates for mantle lithosphere beneath Malo- Botuobinskoe kimberlite pipes

In Upper- Muna field mantle sequence between the Deimos pipe is close in structure to Alakite pipes. Feenriched clinopyroxene - bearing rocks are distributed within the pressure gap $(60-55 \mathrm{kbars})$ in location of ilmenite- forming systems (70-60 and 55-40 kbar), the Ilm- metasomatic veins are situated upper. Rocks with sub-Ca garnets starts from 40 kbar typicaly for Upper Muna field. Mantle beneath Novinka is enriched in Cpx- rocks lower $45 \mathrm{kbar}$, garnet ilmenites are scarse and substituted by Fe-chromites common for other pipes, sub -Ca garnets are abundant from 55 kbars.

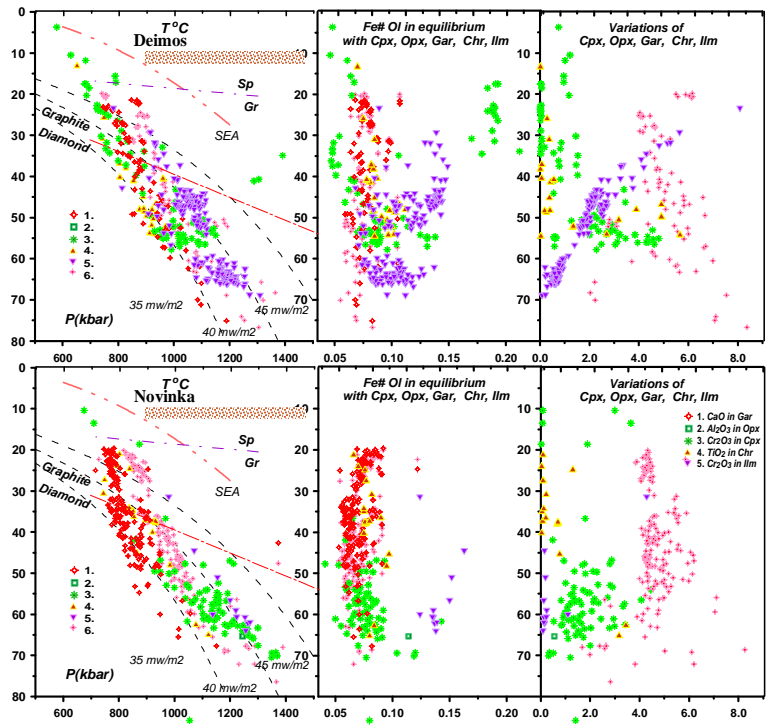

Fig.5. TP estimates for mantle sections beneath UpperMuna kimberlite pipes.

In Nakyn field rithmic layering found for peridotites for lower part ( $\mathrm{P}>40 \mathrm{kbar})$, fertilization by Fe-Cpx (40-50 kbar) followed the Ilm- forming system $\sim 55-60 \mathrm{kbar}$ 
correlating with depleted (low-Ca) peridotites occurence beneath Nurbinskaya. The mantle sequense for Botuobinskayais is similar but peridotite depletion is higher and fertilization starts lower 50 kbar.

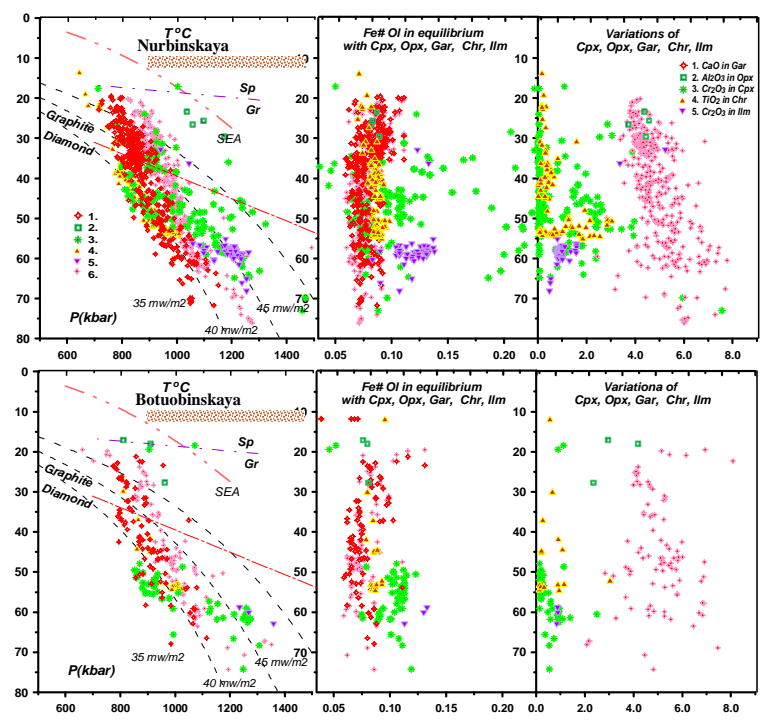

Fig.6. TP estimates for mantle in Anabar field.

In Anabar fields highly depleted mantle is subjected to $\mathrm{Fe}$ - metasomatites followed ilmenite growth $\mathrm{P}>40$ kbars and abundant Gar-CPx rocks are typical uppper. Mantle beneath Trudvaya includes the relics of low- $\mathrm{T}^{\mathrm{O}}$ peridotites and pervasive protokimberlite feeders to 40 kbars. Essential fertilization take place in upper section. Cr-low ilmenites from lower part of mantle lithosphere prevail in this region.

Mesozoic pipes from Kuoyka (Olenek region) and Chompolo field (Aldan) reveal highly $\mathrm{Fe}$ metasomitized mantle series below $40 \mathrm{kbar}$ and more strong in the level of upper asthenospheric lens. The relics of $\mathrm{Mg}$-peridotites froming $\mathrm{LT}$ branch and $\mathrm{Cr}$ bearing HT metasomatites occur in lower mantle part.

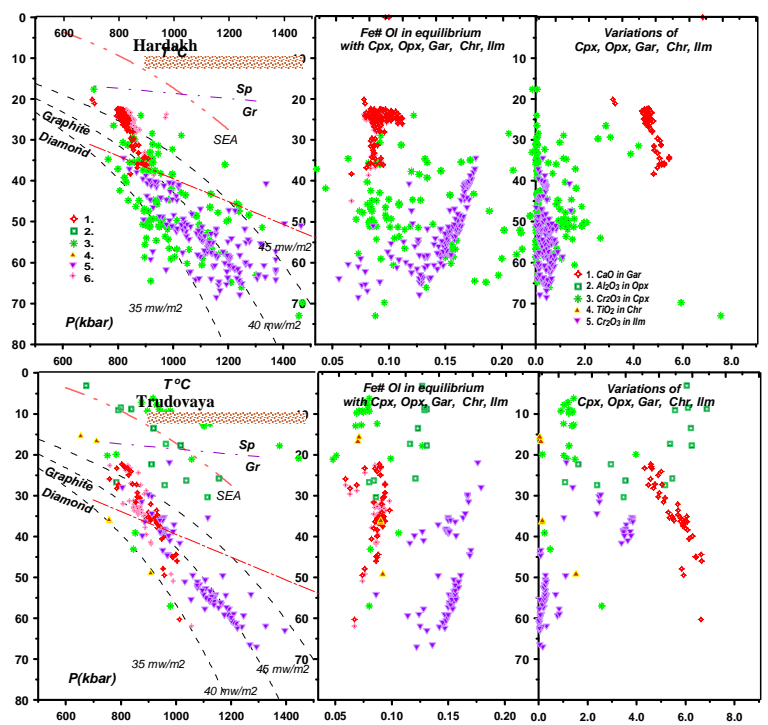

Fig.5. TP estimates for mantle sections beneath Anabar kimberlite pipes.

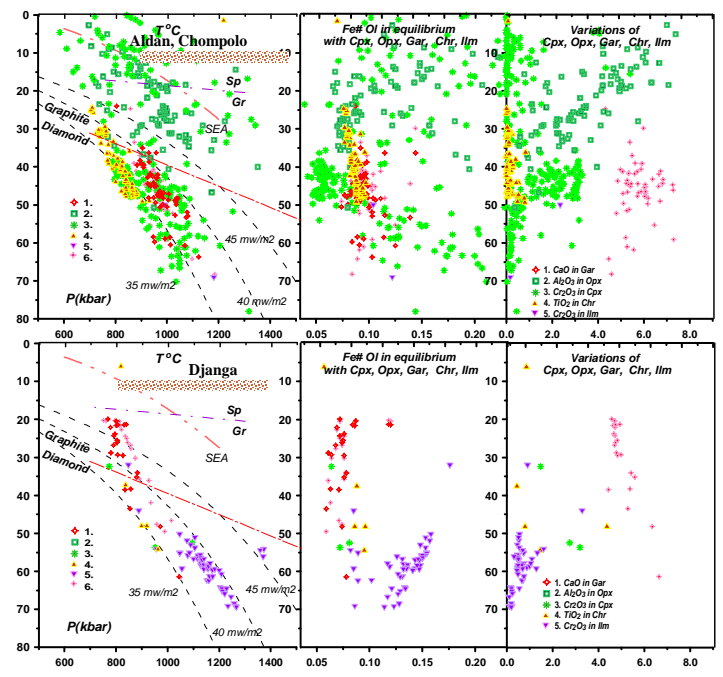

Fig.7. TP estimates for mantle in mesozoic Aldan and Olenek kimberlite fields.

\section{References.}

Ashchepkov, I.V., Pokhilenko, N.P., Vladykin, N.V., Rotman A.Y., Afanasiev V.P., Logvinova A.M., Kostrovitsky S.I., Pokhilenko L.N., Karpenko M.A., Kuligin S.S., Malygina E.V., Stegnitsky Y.B., Alymova N.V. Khmelnikova O.S. 2008. Reconstruction of mantle sections beneath Yakutian kimberlite pipes using monomineral thermobarometry. Geological. Society of London (SP). 293, 335-352.

Boyd, F.R., Pokhilenko, N.P., Pearson, D.G., Mertzman, S.A., Sobolev, N.V., Finger, L.W. 1997. Composition of the Siberian cratonic mantle: evidence from Udachnaya peridotite xenoliths. Contrib. Mineral. and Petrol. 128, 228-246

Brey, G.P., Kohler, T. 1990. Geothermobarometry in fourphase lherzolites. II. New thermobarometers, and practical assessment of existing thermobarometers. Journal of Petrology, 31, 1353-1378.

Nimis, P., Taylor, W., 2000 Single clinopyroxene thermobarometry for garnet peridotites. Part I. Calibration and testing of a Cr-in-Cpx barometer and an enstatite-in-Cpx thermometer. Contributions to Mineralogy and Petrology, 139, 541-554

O'Neill, H.St.C, Wood, B.J., 1979. An experimental study of Fe-Mg- partitioning between garnet and olivine and its calibration as a geothermometer. Contributions to Mineralogy and Petrology, 70, 5970.

Krogh E. J., 1988. The garnet-clinopyroxene Fe-Mg geothermometer a reinterpretation of existing experimental data. Contributions to Mineralogy and Petrology, 99, 44-48.

Pokhilenko N. P., Sobolev N.V., Kuligin, S. S., Shimizu, N. 2000. Peculiarities of distribution of pyroxenite paragenesis garnets in Yakutian kimberlites and some aspects of the evolution of the Siberian craton lithospheric mantle. Proceedings of the VII International Kimberlite Conference. The P.H. Nixon volume. P. 690-707. 602.

Sobolev N.V. 1977 Deep-Seated Inclusions in Kimberlites and the Problem of the Composition of the Upper Mantle. Am. Geophys. Union. Washington, D.C.

Taylor W.L., Kamperman M., Hamilton R., 1998. New thermometer and oxygen fugacity sensor calibration for ilmenite amd Cr-spinel- bearing peridotite assemblage. 7th IKC Extended abstracts., 891. 